\title{
Agronomic evaluation of perennial ryegrass wild populations from Ireland for use in French plant breeding programmes
}

\author{
G. Charmet ${ }^{1}$, A. Bion ${ }^{1}$ et F. Balfourier ${ }^{2}$ \\ 1 INRA, station d'amélioration des plantes, 63039 Clermont-Ferrand; \\ 2 INRA, domaine experimental fourrager, Le Pin au Haras 61310 Exmes, France
}

(received 16 january 1989, accepted 12 september 1989)

Summary - A sample of 60 wild populations of perennial ryegrass (Lolium perenne L.) from Ireland (joint EEC-An Foras Taluntais collection 1981-83) was evaluated at 3 locations in France covering a wide range of agroclimatic conditions, either as spaced plant nurseries or as microplots in comparison with commercial controls. After an analysis of variance, the mean population effects for 13 quantitative traits, together with an index of general agronomic value for each location, were submitted to a principal component analysis followed by a hierarchical clustering. One of the 4 clusters obtained includes populations which perform as well as the control cultivars "Vigor" or "Preference" in the 3 locations. This material could then be very useful as a source of diversification germplasm for use in French breeding programmes.

perennial ryegrass - genetic resources - multivariate analysis - hierarchical clustering

Résumé - Evaluation agronomique de populations irlandaises de ray grass anglais pour utilisation dans les programmes d'amélioration. Un échantillon de 60 populations de ray grass anglais (Lolium perenne $L$.) provenant d'une collecte conjointe CEE - An Foras Taluntais en Irlande a été évalué en 3 lieux en France représentant différentes régions agroclimatiques, soit en pépinières de plantes isolées, soit en microparcelles en comparaison avec des témoins commerciaux. L'analyse de variance de 11 caractères agronomiques (Tableau II) montre que l'effet moyen population est toujours significatif par rapport à l'interaction génotype x milieu, sauf pour le caractère "vigueur au printemps". Les populations irlandaises présentent en moyenne des performances moins bonnes que les variétés témoins, notamment pour la résistance au froid et la croissance en automne. La variabilité est cependant supérieure et les meilleures d'entre elles peuvent présenter des niveaux intéressants, par exemple pour la résistance à la rouille couronnée ou l'absence de remontaison. Les valeurs moyennes des populations ainsi qu'un index de valeur agronomique globale pour chaque lieu ont ensuite été soumis à une analyse en composante principale (Figs. 2 et 3). Les 4 premières composantes expliquent $85 \%$ de l'inertie totale du nuage, avec un premier axe très corrélé positivement à toutes les notes de vigueur et à la résistance au froid. L'axe 2 oppose l'alternativité à la tardiveté d'épiaison tandis que l'axe 3 oppose la sensibilité à la rouille et à la remontaison.

Une classification hiérarchique ascendante à partir des 6 premières composantes principales permet d'obtenir une partition en 4 classes (Fig. 1) pour laquelle le rapport inertie interclasses/inertie totale est de 0,58. Les classes sont illustrées par une double représentation graphique, à la fois sur les plans 1-2 et 1-3 de l'analyse en composante principale et sur la carte d'Irlande (Fig. 4). Les classes 3 et 4 présentent des valeurs positives pour la composante 1 qui peut être considérée comme un index de vigueur. La classe 4, qui comprend 5 populations tardives, représentant pour les objectifs de sélection français le matériel le plus intéressant. La seule relation significative avec les facteurs écologiques des sites de collecte concerne la température moyenne de juillet : les populations de la classe 2 provenant toutes des zones fraîches tandis que celles de la classe 4 sont originaires des zones côtières du Sud-Est de l'Irlande, plus «chaudes».

ray grass anglais - ressources génétiques - analyse des données - classification hiérarchique 


\section{INTRODUCTION}

Perennial ryegrass is one of the grasses most commonly used in France, either in pure stand or mixed with white clover, for sowing temporary meadows or regenerating permanent pastures, this species being greatly appreciated for its high nutritive value.

In most regions of France however climatic stresses can limit the production of perennial ryegrass and its repartition throughout the year. Therefore, in order to provide cultivars more adapted to a wide range of agroclimatic conditions, including semi-continental and hill areas, a breeding programme on this species has been carried out since 1983 at the Institut National de la Recherche Agronomique (INRA). The main breeding goals are the improvement of stress tolerance (drought, late spring frost ...) and the persistence in severe conditions together with a high quality and adaptation to grazing, leading us to give preference to late flowering, and "stemless" material (compatible, however, with enough seed production).

As a contribution to our initial germplasm, we received a collection of about 250 wild populations collected from old pasture ecosystems in Ireland. This paper describes the results of a multilocal evaluation of 60 Irish ryegrass populations randomly sampled. This preliminary survey is aimed at comparing this wild material to the cultivars available to-date and to identify original sources of genes for traits of agronomic interest.

\section{MATERIAL AND METHODS}

Sixty ryegrass populations from the EEC collection were randomly sampled and studied at 3 locations in France: Clermont-Ferrand is an inland plain with a semi-continental climate, Bourg Lastic is in the wet hill of Massif Central and Le Pin au Haras in the oceanic Normandy. Table I summarizes the main characteristics of these locations. Ten cultivars chosen among the most available varieties of the French official list were used as controls.

In the spring of 1986, at Clermont-Ferrand and Bourg Lastic, populations were sown in a glasshouse and then transplanted in the field, $40 \mathrm{~cm}$ apart. The design consisted of 2 complete randomized blocks with 30 plants of each population per block. Eleven characters listed below, were observed on a single plant basis and noted on a visual scale.

- in 1986

(1) alternativity: from $1=$ none to 9 = very (early apparition of many spikes)

(2) tillering from 1 = few to $9=$ many tillers

(3) growth habit from $1=$ erect to $9=$ prostrate

(4) crown rust susceptibility from $1=$ resistant to $9=$ very susceptible.

- in 1987 died

(5) frost susceptibility from $1=$ no change to $9=$

(6) early spring growth from $1=$ low to $9=$ high

(7) aftermath heading from $1=$ none to $9=$ many spikes

(8) summer growth from $1=$ dormant to $9=$ abundant

(9) autumn regrowth from $1=$ few to $9=$ abundant - in 1988

(10) persistence from $1=$ low to $9=$ high level

(11) heading date (rank of the day)

Most of these observations were made at both locations except for traits (1), (2), (3) and (11) only at Clermont-Ferrand.

At le Pin au Haras, populations were sown in June 1986 in a 4 replicated microplot trial, with two, $1 \mathrm{~m}$ long rows of each population per block. Dry matter yield was measured in 1987 (5 cuts) and 1988 (3 cuts). Yield data (showing significant population effects for every cut) were summed, for each population and only 2 variates namely (12) 1st year dry matter yield and (13) 2nd year DMY were used in further analysis.

Table I. Main climatic characteristics of the 3 locations.

\begin{tabular}{|c|c|c|c|c|c|}
\hline Location & Region & Altitude & $\begin{array}{c}\text { Average minimum } \\
T^{\circ} \text { of January } \\
\left({ }^{\circ} \mathrm{C}\right)\end{array}$ & $\begin{array}{c}\text { Average maximum } \\
T^{\circ} \text { of July } \\
\left({ }^{\circ} \mathrm{C}\right)\end{array}$ & $\begin{array}{c}\text { Annual } \\
\text { rainfall } \\
(\mathrm{mm})\end{array}$ \\
\hline $\begin{array}{l}\text { Clermont } \\
\text { Ferrand }\end{array}$ & $\begin{array}{c}\text { Auvergne } \\
\text { (plain) }\end{array}$ & 350 & -0.8 & 25.5 & 580 \\
\hline $\begin{array}{l}\text { Bourg } \\
\text { Lastic }\end{array}$ & $\begin{array}{l}\text { Auvergne } \\
\text { (mountain) }\end{array}$ & 850 & -3.0 & 21.4 & 1160 \\
\hline Le Pin au Haras & Normandy & 150 & 1.5 & 22.2 & 700 \\
\hline
\end{tabular}


Spaced plant data of most traits from Clermont and Bourg Lastic were analysed together through an analysis of variance using the model

$$
X=M u+L o+L o . b l+P o+L o . P o+E R R
$$

where $\mathrm{Mu}=$ overal average; Lo = location effect; Lo.bl $=$ block within location effect; $P$ o $=$ population main effect; Lo.Po = population $\times$ location interaction; $E R R=$ residual.

Since the main population effects were found to be significant when tested against population $\times$ location interaction, these population effects were used in further analyses (except for early spring growth for population $x$ interaction was preponderant and the data from Clermont-Ferrand only were used, see below). In addition, 2 phenotypic indices of "general agronomic value" at each location were calculated as the sum of the terms Po + Lo.Po for the traits (4) to (10) with equal weights.

Data of traits (1), (2), (3) and (11) observed only at Clermont-Ferrand and also for trait (6) were analyzed using the model $x=M u+b l+P o+E R R$.

Principal component analysis of the correlation matrix allows the multidimensional data to be summarized by a limited number of new orthogonal variates : such an analysis has been carried out on the "population main effects" from the analysis of variance on 1 or 2 location designs as indicated above and on the population means for annual dry matter yield at Le Pin. Irish wild populations played an active role in this analysis whereas the controls were added as illustratives.

Euclidian distances between populations were computed from their coordinates on the 1 st 6 principal components (the standardized euclidian distance being used in this way). An ascendant hierarchical clustering was then carried out using the Ward criteria (minimal loss among clusters variance at each step) as aggregation method (INRIA, 1987).

A partition was chosen from the view of the tree of classification, and each population was graphically represented on both principal component plans and map of Ireland by a symbol for each clusters as indicated in Carrel et al. (1986).

Much information concerning location, ecology, management and past history was recorded at the time of population sampling and the following traits were used as illustrative variates. $\chi^{2}$ tests were performed for testing their randomness from one cluster to each other.

- soil texture, 4 classes : light - medium - heavy very heavy clay.

- drainage, 2 classes : free - impeded.

- soil pH, 3 classes : acid ( $<5.5)$, neutral, basic $(>6.5$ )

- nitrogen applied, 3 classes: low $(<50)$, medium, high (> 150).

- grazing intensity, 3 classes : lax - medium intensive.

- ryegrass abundance, 3 classes : rare - frequent abundant

- white clover abundance, 3 classes : rare - frequent abundant

- poaching, 4 classes : none - moderate - slight severe

- maximum average temperature in July, 2 classes: $<19 \rightarrow 19^{\circ} \mathrm{C}$

- minimum average temperature in January, 2 classes : $<2.5->2.5^{\circ} \mathrm{C}$

- annual rainfall, 2 classes : $<1000->1000 \mathrm{~mm}$

- altitude above see level, 2 classes : $<100->100 \mathrm{~m}$

\section{RESULTS}

Average values, range of variation of population means and mean squares of the 15 traits studied are presented in Table II. Wild ryegrass populations from Ireland show on average less interesting performances than commercial

Table II. Summary statistics and mean squares analysis on 15 traits.

\begin{tabular}{|c|c|c|c|c|c|c|c|c|c|}
\hline \multirow[b]{3}{*}{ Alternativity } & \multicolumn{3}{|c|}{ Populations } & \multicolumn{3}{|c|}{ Control } & \multicolumn{3}{|c|}{ Mean squares } \\
\hline & \multirow{2}{*}{$\frac{\text { Average }}{2.13}$} & \multicolumn{2}{|c|}{ Range } & Average & \multicolumn{2}{|c|}{ Range } & \multirow{2}{*}{$\frac{\text { Population }}{5.80^{\star \star}}$} & \multirow{2}{*}{$\frac{\text { Pop } \times \text { loc interaction }}{-}$} & \multirow{2}{*}{$\frac{\text { error }}{0.94}$} \\
\hline & & 1.65 & -3.17 & 2.09 & 1.93 & -2.38 & & & \\
\hline Tillering & 4.16 & 3.20 & -4.85 & 4.43 & 4.22 & -4.73 & $8.42^{\text {* }}$ & - & 1.96 \\
\hline Growth habit & 6.56 & 5.18 & -7.85 & 5.17 & 4.04 & -5.85 & $20.36^{\star *}$ & - & 2.03 \\
\hline Crown rust susc. & 4.79 & 3.95 & -5.33 & 4.95 & 4.79 & -5.07 & $16.06^{\star \star}$ & $4.70^{*}$ & 1.00 \\
\hline Frost susc. & 4.75 & 3.93 & -6.07 & 4.16 & 3.87 & -4.50 & $28.85^{\star \star}$ & $7.39^{\star \star}$ & 1.49 \\
\hline Early spring growth & 3.17 & 2.29 & -3.92 & 3.69 & 3.37 & -3.92 & $9.95 \mathrm{~ns}$ & $9.05^{\star \star}$ & 0.87 \\
\hline Aftermath heading & 3.28 & 2.15 & -4.54 & 4.07 & 3.52 & -4.64 & 34.94 ** & 10.90 & 2.54 \\
\hline Summer growth & 3.92 & 3.35 & -4.33 & 4.10 & 3.83 & -4.46 & $9.10^{*}$ & $3.42^{\text {** }}$ & 0.95 \\
\hline Autumn regrowth & 2.50 & 1.81 & -3.13 & 3.19 & 2.90 & -3.43 & $19.92^{\star \star}$ & $4.66^{\star *}$ & 1.46 \\
\hline Persistence & 2.53 & 1.72 & -3.30 & 3.10 & 2.78 & $3-3.44$ & $16.43^{\star \star}$ & $4.72^{*}$ & 1.19 \\
\hline Heading date & 14.26 & 126 & $-\quad 162$ & 150 & 124 & -165 & $2800^{\star \star}$ & - & 48.50 \\
\hline First year DMY & 12.56 & 9.08 & -18.18 & 16.5 & 8.44 & -19.61 & $24.19^{\star \star}$ & - & 3.20 \\
\hline Second year DMY & 7.63 & 4.80 & -10.63 & 9.80 & 8.4 & -11.22 & $18.56^{\star \star}$ & - & 2.80 \\
\hline General value at CF & -0.73 & -5.35 & -+2.88 & 1.48 & -0.25 & -+3.77 & & & \\
\hline General value at $B L$ & 0.13 & -4.83 & -+4.83 & 1.13 & -1.10 & -+3.20 & & & \\
\hline
\end{tabular}

Population mean squares are tested against interaction MS for traits measured in two locations, otherwise against error MS

Population by location interaction MS being tested against error MS.

$\because *$ indicate when $\mathrm{F}$ ratio is significant at the $5 \%$ and $1 \%$ level respectively 
controls. It is particularly true for tillering (which can be associated with a more erect growth habit), frost susceptibility, early spring and autumn growth, persistence and dry matter yield. However, since wild populations have a wider range of variation than controls, the best ones are to be found at the level of the best controls for most traits or even better for some ones like crown rust resistance, aftermath heading (less) and index of general agronomic value in hill conditions (Bourg Lastic BL).

Table III shows the correlation coefficients between the 15 initial variates and the 1st 4 principal components calculated from the correlation matrix. These 4 components explain $85 \%$ of the total variance. From this table, the 1 st principal component or axis can be called a "vigour axis", since all the seasonal growth notations as well as yield, persistence and indices of general agronomic value are positively correlated, while frost susceptibility remains negative. Indeed, none of these traits are independent from each other; especially the 2 indices of general agronomic values which are linear functions of vigour traits and genotype by location interactions.

These indices are highly correlated to each other and to the yield in Normandy. However, the index of general value in hill condition is more correlated with average summer and autumn growth, while the index of general value in semi-continental plain is more influenced by persistency and quite surprisingly, frost tolerance (this point can be explained by frequent frost without snow cover in plain).
Axis 2 illustrates an opposition between alternativity and heading date whereas axis 3 opposes rust susceptibility to aftermath heading. Component 4 represents growth habit only.

Hierarchical classification from the 1st 6 principal components leads to the tree presented in Figure 1. This Figure suggests that the tree be

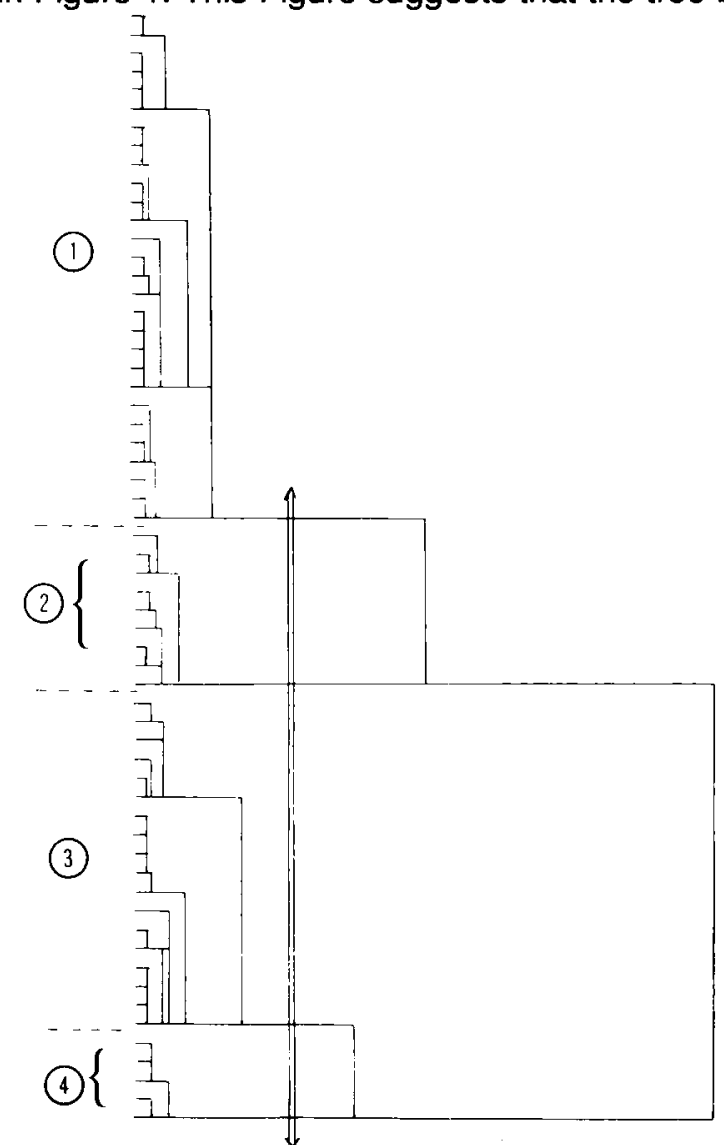

Fig. 1. Hierarchical 3 of the 60 populations and the chosen partition into 4 clusters.

Table III. Correlation coefficients between initial variates and principal components.

\begin{tabular}{lrrrr}
\hline Character & Comp 1 & Comp 2 & Comp 3 & Comp 4 \\
\hline Alternativity & 0.58 & 0.66 & -0.11 & 0.08 \\
Tillering & 0.66 & 0.47 & -0.15 & 0.10 \\
Growth habit & -0.41 & 0.02 & 0.15 & 0.82 \\
Rust susceptibility & 0.30 & 0.15 & $-\mathbf{0 . 8 0}$ & -0.26 \\
Frost susceptibility & -0.91 & -0.22 & -0.15 & -0.14 \\
Spring growth & 0.81 & 0.41 & -0.08 & -0.23 \\
Aftermath heading & 0.31 & 0.55 & 0.67 & -0.08 \\
Summer growth & 0.81 & -0.44 & -0.32 & 0.20 \\
Autumn growth & 0.88 & -0.33 & 0.04 & 0.12 \\
Persistence & 0.96 & -0.11 & 0.11 & 0.12 \\
Heading date & -0.40 & -0.80 & 0.10 & -0.17 \\
First yield & 0.63 & -0.34 & 0.46 & -0.15 \\
Second year yield & 0.62 & -0.31 & 0.37 & -0.33 \\
General value CF & 0.89 & -0.21 & 0.00 & 0.13 \\
General value BL & $\mathbf{0 . 7 5}$ & -0.53 & -0.24 & 0.17 \\
& & & & 7.3 \\
\% variance explained & 48.3 & 18.0 & 11.4 & 85.0 \\
\% cumulated variance & 48.3 & 66.3 & 77.7 & \\
\hline
\end{tabular}


cut at the 4 clusters' level. The partition shows a between-clusters-variance/total variance ratio of 0.58 , which is quite high for such a low number of classes. This means that the clusters are markedly distinct in the multidimensional space. This can be seen on the projection of individual populations onto the plans defined by the principal components 1-2 (Fig. 2) and 1-3 (Fig. 3), each population being represented by a cluster symbol.

Cluster 2, with low values for the vigour notes and persistence, is opposed, along the 1st axis,

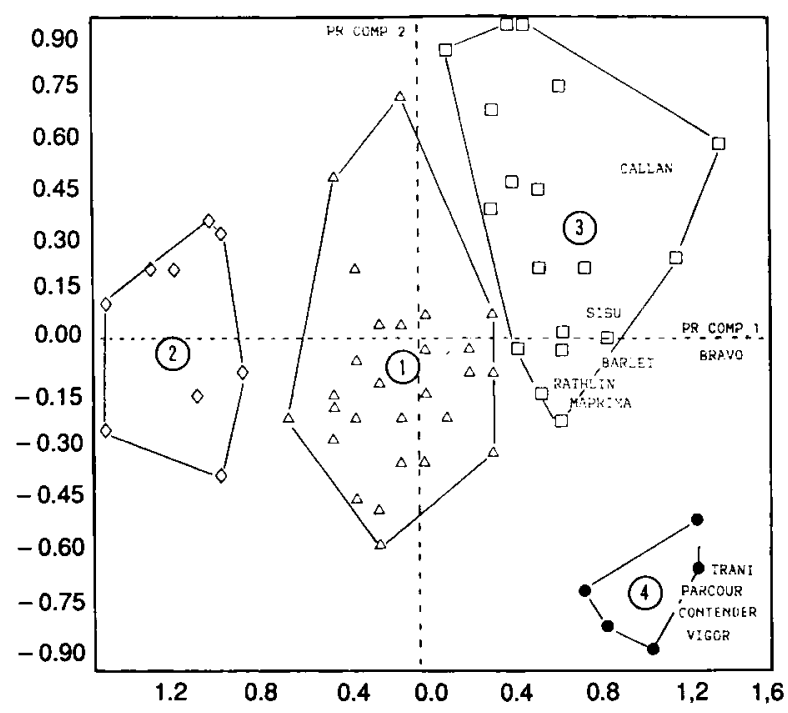

Fig. 2. Projection of the individual population onto the plane defined by the principal components 1.2.

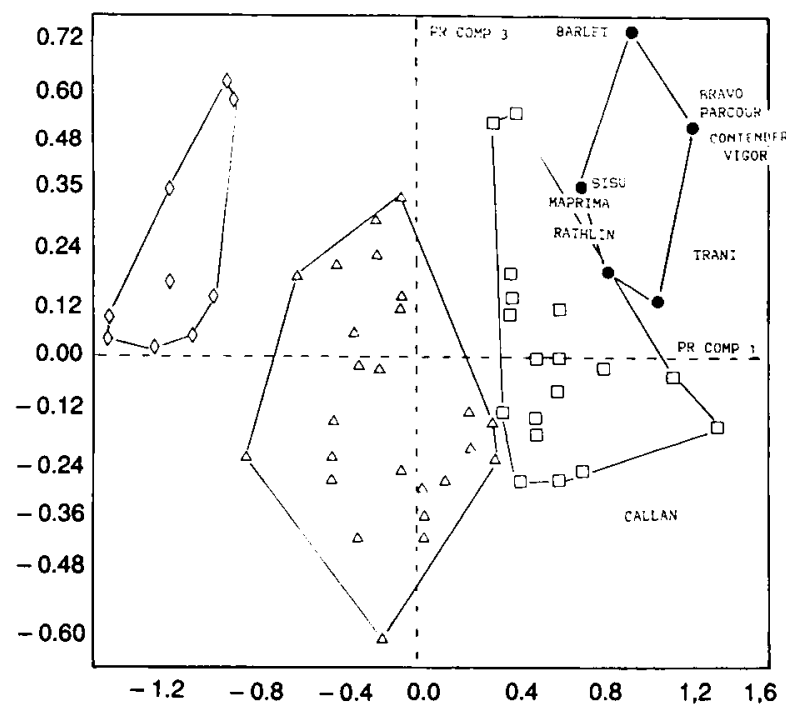

Fig. 3. Projection of the individual population onto the plane defined by the principal components 1-3. The position of the cultivars is on the middle of their name. to clusters 3 and 4 . The latter 2 classes are separated along the 2nd axis, which represents the developmental traits : populations of cluster 3 show an earlier heading date and more alternativity than the populations of cluster 4 . Populations of cluster 1 show values with an overall average for most traits, and a tendency to be more susceptible to crown rust. At the opposite side along axis 3 , we found mainly populations of cluster 3 and cluster 4 to be more resistant to rust. The 10 control cultivars show high positive scores of the 1st component and are distributed along the 2nd axis according to their heading date : early (Callan), intermediate (Sisu, Bravo) or late (Contender, Trani, Parcour, Vigor).

Thus, when compared to commercial cultivars, the 5 populations of cluster 4 and the best ones of cluster 3 show as high a value as controls for traits of agronomic interest. Since the French market requires mainly late and non alternative varieties for pasture use, the populations of class 4 seem to be the most valuable material as genetic resources for our breeding goals.

The geographic localisation of each population with a symbol for each cluster is given in Figure 4. No clear pattern of distribution can be seen on this map of Ireland : populations of clusters 3 and 4 are mainly in the southern and eastern coastal region while populations of cluster 1 are more frequent in the north, but a large overlap does occur. This fact is confirmed by $\chi^{2}$ test showing that the distribution of illustrative ecological variates among the 4 clusters does not significantly differ from random, with the

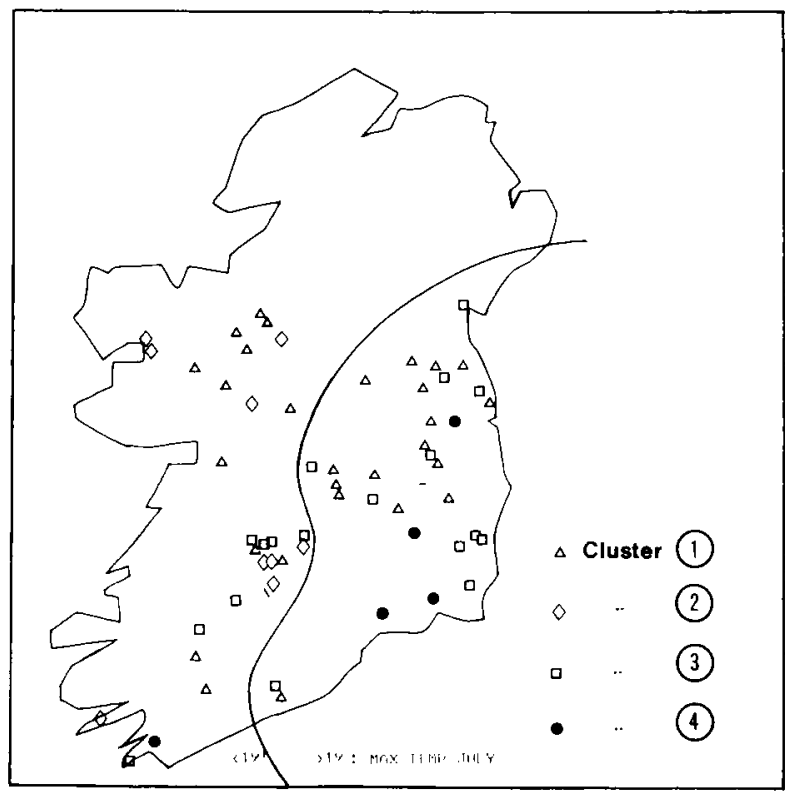

Fig. 4. Geographic distribution of the populations belonging to the 4 defined clusters. 
exception of the mean temperature of July $\left(\chi^{2}=\right.$ $12.207-1$ degree of freedom probability 0.007$)$. The isotherm line $19^{\circ}$ is reported in Figure 4 and populations of cluster 2 are located on the "cold side" whereas 4 out of 5 populations of cluster 4 are on the "warm summer side".

\section{DISCUSSION AND CONCLUSION}

Evaluation of forage grasses wild populations through multivariate analysis (i.e. factorial analysis followed by a clustering method) has been used by Falcinelli et al. (1987) and Veronesi \& Falcinelli (1988) from spaced plant data studied at 1 location in Italy. Hayward et al. (1982) also classified a collection of Lolium multiflorum populations from yield data at several cuts. The present study used a similar method from a multilocal experiment: 2 spaced plants and 1 plot trials location. The yield assessment occurred in Normandy which, in France is the most favourable region for ryegrass growth and thus the yield measures represent in our minds the "potential yield" of ryegrass populations. The objective in spaced plant evaluation was to define an index of general agronomic value for each population from the traits of agronomic interest which are easy to observe and reproducible, in order to find a quite stable typology of the material. Therefore, we used the classical wide spacing method instead of the narrow spacing proposed by Valle Ribeiro (1970) as a method giving results more consistent with sward density experiments.

In what way can the results of multivariate analysis of "genetic resources" be used?

A first approach might be to consider the scores of each "selection unit" (here wild population) on the principal components as an alternative to the Smith-Hazel selection index. Godshalk \& Timothy (1988) show that the ranking based on principal components is highly correlated with that based on the Smith-Hazel index and the former does not require a genetic parameter estimate to be constructed. In this study, the first principal component clearly appears to be useful for this purpose since it is correlated to the growth notations and persistence and negatively to frost susceptibility. Populations of cluster 4 and 3 or 4 of cluster 3 are thus at the level of the control average (about 0.8) and some of them have similar, but not higher, values than the best controls such as "Vigor" (1.2). Since the French market mainly requires late varieties for grazing use, populations of cluster 4 appear to be the most promising material. Indeed, it is quite satisfactory to observe that, even if the wild populations are much more variable than commercial lines, the best one may challenge available cultivars. However we ave pointed out precisely the limitations of these cultivars to many French conditions: thus Irish wild populations in their "native" forms are not an answer to our breeding goals. The question arises as to whether wild populations can still be improved by selection or not, and to what level?

The answer now requires the knowledge of the genetic parameters for the traits to be improved. However it would be costly to estimate variance and covariance components of genetic variation for each population.

Therefore, the second approach of using multivariate analysis is to give us a criteria for pooling wild populations : this has been achieved with the hierarchical clustering based on euclidian distance for agronomic traits. Thus a polycross of 50 plants taken from the 5 populations of cluster 4 was made in order to obtain variance and covariance components from the study of a random sample of halfsib families as described for example by Burgess \& Easton (1986) on New-Zealand wild ryegrass populations. The knowledge of these parameter will enable us to predict theoretical genetic gain by either family and/or mass selection, to compute selection indices and to determine an optimal strategy for recurrent selection. The hypothesis which has been made is that the genetic parameters of populations from within a cluster are more similar than those of populations belonging to different clusters and that the polycross will built a new population with homogeneous parameters to handle quantitative genetic methods. Another polycross has been performed with plants from the 4 cultivars "Contender", "Trani", "Parcour" and "Vigor" in order to compare their genetic parameters and their ability to be further improved by selection with those of wild populations.

Few relationships were found between ecological variates and agronomic traits. Such relations have been found in New-Zealand ryegrass between available $P$ in the soil and vigour, but only for a period of 1 year of observation out of 3 (Forde \& Suckling, 1980); between perennity and ceno-ecological indices in Romania (Kovacs, 1981) and between altitude, rainfall and multivariate clustering in Italian perennial ryegrass populations (Falcinelli et al. 1987).

The one significant relationship was found with average temperature in July: populations of cluster 2 grow in "cool summer" regions whereas 
4 out of 5 populations grow in "warm summer" south west regions. Indeed, the $19{ }^{\circ} \mathrm{C}$ threshold is quite arbitrary, but this relationship seems to be consistent. Thus, in order to find other populations representative of the cluster 4 group, it is advisable to search mainly in the "warmer" part of Ireland : but populations of cluster 1 and 3 may also be found in the same area.

This preliminary study allows us to identify some promising populations which are of the level of the best available cultivars. It remains to be seen whether wild material do in fact represent an original source of genetic variation and whether they can effectively be improved by selection.

\section{REFERENCES}

Burgess R.E. \& Easton H.S. (1986) Old pasture populations of ryegrass in New Zealand and their use in plant breeding N.Z. Agron. Soc. Spec. Publication $\mathrm{n}^{\circ} 5,295-300$

Carrel G., Barthelemy D., Auda Y. \& Chessel D. (1986) Approche graphique de l'analyse en composante principale normée : utilisation en hydrobiologie. Acta Oecol. Oecol. Gen. 7, 189-203
Falcinelli M. Veronesi F. \& Lorenzetti S. (1987) Evaluation of an Italian germplasm collection of Lolium perenne $\mathrm{L}$. through a multivariate approach. In: Natural Variation and Breeding for Adaptation, Proc. Eucarpia Fodder Crop Section Meeting, Lusignan, 22-24 Sept

Forde M.B. \& Suckling F.E.T. (1980) Genetic resources in high-rainfall hill pastures of New Zealand II. Description of the ryegrass collection. N.Z. J. Agric. Res. 23, 179-183

Godshalk E.B. \& Timothy D.H. (1988) Factor and principal component analysis as an alternative to index selection Theor. Appl. Genet. 76, 352-360

Hayward M.D., De Lacey I.H., Tyler B.F. \& Drake D.W. (1982) The application of pattern analysis for the recognition of adaptation in a collection of Lolium multiflorum populations. Euphytica 31, 383-396

INRIA (1987) Modulad: Bibliothèque Fortran 77 pour l'analyse des données, Institut National de Recherche en Informatique et Automatique, Paris

Kovacs A.J. (1984) Some aspects concerning adaptative variability in Lolium perenne L. populations. Probl. de Genet. Teor. si Apl. (Romania) 16, 153-165

Valle Ribeiro A.M. (1970) Assessment and selection of initial material for breeding perennial ryegrass (Lolium perenne L.). J. Agric. Sci. Cam. 74, 433-444

Veronesi F. \& Falcinelli M. (1988) Evaluation of an Italian germplasm collection Festuca arundinacea Schreb. through a multivariate analysis. Euphytica 38, 211-220 